\title{
The Relationship between Servant Leadership, Perceived Organizational Support, Performance, and Turnover among Business to Business Salespeople
}

\author{
James B. DeConinck \\ School of Marketing, Entrepreneurship, Sport Management, and Hospitality \& Tourism \\ Western Carolina University \\ Mary Beth DeConinck \\ School of Marketing, Entrepreneurship, Sport Management, and Hospitality \& Tourism \\ Western Carolina University
}

\begin{abstract}
The purpose of this study, using a sample of 382 business-to-business salespeople in the United States, was to investigate how servant leadership influences salespersons' perceived organizational support (POS), outcome performance, turnover intentions, and turnover. The results showed that servant leadership had a direct influence on POS and performance, but was related only indirectly to both turnover intentions and turnover through POS and performance.
\end{abstract}

Key Words - Servant leadership, perceived organizational support, performance, turnover intentions, turnover

\section{INTRODUCTION}

Leadership has been an important area of research in professional sales because of its relationship to important job attitudes and behaviors [40]. While sales researchers have investigated various leadership theories such as ethical leadership [19, 79], participative and instrumental leadership [57]; transformational/transactional leadership [6, 55, 60, 81, 83], supportive leadership [41, 61], and leader-member exchange [17, 64], in recent years increased attention has been devoted to servant leadership involving employees in a variety of occupations [50, 51, 87] including professional selling [42, 43, 44, 77].

The concept of servant leadership was developed many years ago [30,31]. But, since only the early 2000s has it drawn the interest of scholars. Servant leaders emphasize the followers' development and growth $[41,51]$ directly through mentoring or indirectly by providing a supportive work environment [51]. Servant leaders view their role as developing followers' responsibility and autonomy [87]. They place followers' needs and interests above their own needs and interests $[4,51]$. Servant leaders act the same in all aspects of their lives [51]. The key aspect of servant leadership is to serve others [31].

Servant leadership is related to a variety of job attitudes and behaviors such as organizational commitment [51], organizational justice [25, 78, 90], organizational citizenship behavior [49, 62], and psychological contract fulfillment [63]. While these studies have provided insights into understanding servant leadership's influence on employees' attitudes and behavior, several questions remain. First, what is the relationship between servant leadership and performance? The issue of performance is particularly relevant in professional selling because the firm's revenue is partially dependent upon the performance of the sales force [12]. 
The results of prior research are inconclusive regarding the relationship between the two variables. For example, some research indicates a direct relationship between servant leadership and performance $[42,49,77]$ while other research indicates that the relationship is mediated by other variables $[3,13,44]$. Thus, does the sales manager who is viewed as a servant leader directly influence salespersons' performance? This study will attempt to provide further clarification into the relationship between servant leadership and salespersons' performance.

Second, what is the relationship between servant leadership and perceived organizational support (POS)? POS, "the extent to which employees perceive that their contributions are valued by their organization and that the firm cares about their well-being" [23, p. 501], has been the focus of many studies during the last 30 years and has been linked to a variety of job attitudes and behaviors [71]. A few studies have reported that POS is related positively to several leadership theories such as transformational leadership [24] and leader-member exchange $[85,92]$. However, a search of the literature found only one study that analyzed the relationship between servant leadership and POS [95]. This study, which involved Chinese public-sector employees, reported a positive relationship between POS and servant leadership. Intuitively, salespeople who think their sales manager cares about their well-being and places their needs and interests above his/her own needs and interests should perceive a higher level of perceived organizational support. Given the important relationship of POS to both other leadership theories and various job attitudes and behaviors, a need exists within a sales environment to understand its relationship to servant leadership.

A third important purpose of this study is to examine the relationship between turnover and servant leadership. Much research has been devoted to understanding variables related to turnover [see the meta-analyses by Griffeth et al. and Holtom et al. 2008, 32, 37]. Turnover is especially important in professional selling where the turnover rate can be double the rate for other jobs [72]. While the direct costs of salesforce of turnover is high, the indirect costs (customer retention and the time needed to train a new salesperson) also can be substantial [9].

Previous research investigating the influence of servant leadership among salespeople has used turnover intentions as a surrogate for turnover (e.g. 43, 44, 47, 75, 91]. However, an employee stating a desire to leave is not the same as actually leaving. The meta-analysis by Griffeth, Hom, and Gaertner [32] found that the correlation between turnover intentions and turnover is only .38. Thus, a need exists to examine if the presence of a servant leader in a sales environment actually is related to turnover rather than just the intent to leave.

\section{Servant Leadership}

\section{LITERATURE REVIEW}

Robert Greenleaf [31] developed the concept of servant leadership as defined below: The Servant Leader is servant first...It begins with the natural feeling that one wants to serve, to serve first. Then conscious choice brings ne to aspire to lead...The best test, and difficult to administer is this: Do those served grow as persons? Do they, while being served, become healthier, wiser, freer, more autonomous, and more likely themselves to become servants? And, what is the effect on her least privileged in society? Will they benefit, or at least not further be harmed? $p$. 7). 
Servant leadership shares similarities to other leadership theories (see reviews by Stone, Russell, and Patterson and van Dierendonck, 84, 87). For example, servant leadership overlaps with ethical leadership in three areas: people, humility and development, and empowering people [87]. In contrast to ethical leadership whose main focus is on creating role models who communicate ethical values and rewarding and punishing employees for ethical or unethical behavior, servant leadership emphasizes other dimensions of a leader's behavior [48]. Both servant leadership and transformational leadership emphasize similar leadership attributes: articulating a vision, trust, honesty, integrity, role modeling, and empowerment [84]. However, the major difference between servant leadership and other leadership theories is the leader's focus. The primary focus of servant leaders is on the needs of the follower while transformational leaders focus on organizational effectiveness [65, 87]. While relationships are important to other leadership theories, it is a central component of servant leadership [48]. The servant leader attempts to help followers grow, prosper, and develop [31] and motivates followers by focusing on their needs and behaviors [48]. A servant leader's primary motivation is to serve others [48].

Grisaffe, VanMeter, and Chonko [33] reported that while facets of servant leadership do overlap with other forms of leadership (i.e. transformational and transactional), it does provide incremental increases in salespersons' attitudes and behaviors beyond that of transformational and transactional leadership styles at higher levels of the sales hierarchy. In addition, Liden et al. [51], reported that servant leadership was related positively to organizational commitment and in-role performance, after controlling for the effects of transformational leadership and leader-member exchange. Thus, while servant leadership is similar to other leadership theories, it contains distinct characteristics from them.

During the last ten years, increased attention has been given to servant leadership in the professional selling area. For example, research has reported that servant leadership is related to a caring ethical work climate and performance [42, 77], organizational commitment [44], satisfaction and organizational citizenship behavior [33], organizational justice [78], and turnover intentions [43]. The next section of the paper presents a discussion of variables hypothesized to be outcomes of servant leadership. The hypothesized model appears in the appendix.

\section{Perceived Organizational Support}

Both the norm of reciprocity and social exchange theory is the basis for POS [8]. Blau [8] defined social exchange as "the voluntary actions of individuals that are motivated by the returns they are expected to bring and typically do in fact bring from others" (p. 91). Economic exchanges differ from social exchanges. Economic exchanges involve getting paid for performance at a specified time while social exchanges involve non-specified rewards in the future and involve high levels of trust [29]. Employees who perceive that the organization treats them fairly and cares about their well-being will feel obligated to reciprocate that behavior through increased loyalty, commitment, and performance [22].

Surprisingly, only one study could be located that has examined the relationship between servant leadership and POS [95]. However, a few studies have reported that POS is highly correlated with both leader-member exchange $[21,85,92]$ and transformational leadership [2, 24]. In their meta-analysis of POS Rhoades and Eisenberger [71] reported that perceived supervisor support is correlated highly with POS. However, their study did not report the correlation between any specific leadership theory and POS. Liden et al. [51] theorized that by caring for employees' interests and creating a relationship built on trust, servant leaders display support for followers that extends outside the formal employment relationship. In 
addition, the interactions between servant leaders and subordinates may increase subordinates' perceptions that the organization supports them.

Servant leadership contains similar attributes as those characteristics found in transformational leadership and leader-member exchange. Since both transformational leadership and leader-member exchange theory are correlated highly with POS, intuitively servant leadership also should be related to POS.

H1: Servant leadership is related positively to POS.

\section{Servant Leadership and Performance}

Researchers have been particularly interested in studying leadership and its relationship to performance. Salespeople have the direct responsibility to increase the firm's revenue. Generally, research has shown that various leadership styles can influence performance indirectly through increased job satisfaction, effort, and motivation [43].

While servant leadership has been shown to be related to a variety of employees' job attitudes and behaviors, its relationship to performance is somewhat unclear. For example, both Liden et al. [49] and Chiniara and Bentein [13] found that the relationship between servant leadership and employee task performance was mediated by other variables. Regarding salespeople some research indicates that the relationship between servant leadership and performance is both direct and indirect through other variables [33, 42, 77]. However, Jaramillo et al. [44] reported that servant leadership was related to outcome performance only indirectly through other variables (job satisfaction, organizational commitment, and job stress).

One purpose of this study is to analyze if servant leadership influences salespersons' performance directly or indirectly through other variables. The preponderance of research involving salespeople appears to indicate that servant leadership is related to performance directly. Thus, the following hypothesis will be tested.

H2: Servant leadership is related positively to salespersons' performance.

\section{Antecedents of Turnover}

While turnover is important for all businesses, it especially is important for sales organizations because of the direct and indirect costs. Direct costs include hiring and training new salespeople and lost sales. Turnover rates can reach 50 percent in some industries [10]. Indirect costs include customer retention [75]. A relationship of trust that has developed between the salesperson and the client may be lost when a new salesperson takes over the territory. Another indirect cost is the "ramp-up" time needed to get the new salesperson familiar with the territory [20]. Given these high costs, the number of studies devoted to sales force turnover is not surprising [16].

In order to reduce the costs of turnover organizations need to understand factors related to increased turnover. Prior research has indicated many variables associated with sales force turnover including job satisfaction and organizational commitment [74, 91], leadership style [57], organizational justice [20], ethical climate [45, 82], supervisory trust [59], and performance $[20,57]$. 
Intuitively, when organizations provide help to employees and values their contributions, the employees should reciprocate with positive work-related behavior such as increased effort and performance. Several studies $[15,68,73]$ including the meta-analysis by Rhoades and Eisenberger [71] have shown a positive relationship between POS and job performance. In addition, research has shown that POS is related to turnover intentions [18] and performance is related negatively to turnover intentions/turnover $[32,93,96]$ while turnover intentions are related to turnover $[32,38]$.

H3: POS is related positively to performance.

H4: POS is related negatively to turnover intentions.

H5: Performance is related negatively to turnover intentions.

H6: Performance is related negatively to turnover.

H7: Turnover intentions are related negatively to turnover.

While prior research has indicted a significant correlation between the various leadership theories and turnover intentions [7, 35, 59], most research has reported that other variables mediate or moderate the relationship $[11,19,17,36,57]$.

However, few studies have examined the relationship between servant leadership and turnover intentions. Three studies reported that other variables mediate the relationship [1, $43,95]$ while one study reported that servant leadership was related directly to turnover intentions [39]. Since controlling turnover is very important in professional selling, understanding the relationship between servant leadership and turnover is important.

Although a few studies involving salespeople have used actual turnover $[20,46,53,55,76]$, most sales force research has used turnover intentions as a surrogate for turnover [e.g. 26, 45, $47,58,67]$. However, only 14 percent of the variance in turnover is accounted for with quit intentions [32]. Two recent studies have reported similar results [66, 69]. Thus, just because a salesperson states an intention to quit, does not mean that he or she will actually leave. Therefore, two important purposes of this study are to (1) investigate if servant leadership is related directly to turnover intentions and (2) if servant leadership is related directly to turnover or if these relationships are mediated by other variables.

R1: What is the relationship between servant leadership and turnover intentions/turnover?

\section{METHODOLOGY}

This study employed a cross-sectional group of business-to-business salespeople. A list of 600 sales managers located in the United States was purchased from a commercial broker. Each sales manager was sent a letter explaining the purpose of the study and a copy of the survey. The sales managers who agreed to participate in the study were asked to encourage their salespeople to access a link so that they could complete the survey. The salespeople were assured that only the researchers would have access to their responses. The survey was coded in order to match the salespeople with their sales manager. This situation was necessary since the sales managers provided performance data for each of their salespeople, to track nonresponse bias and evaluate turnover. In order to ensure confidentiality demographic and performance data were obtained prior to the salespeople having access to the survey. Thus, the sales managers were not able to ascertain which of their salespeople chose to complete or not complete the survey.

A total of 38 letters were returned as undeliverable. Of the remaining sales managers, 153 supplied performance and demographic data for their sales force. Completed surveys were 
received from 382 salespeople (59.4 percent). One year later each sales manager was contacted to obtain turnover information. The names of the salespeople who completed the survey one year earlier were compared to the names who had left the company. After one year, 15 salespeople had been promoted and 86 had left the company. The salespeople who were promoted were not counted as turnover.

All of the salespeople were employed in business to business sales position working in both manufacturing and services industries. The salespeople had worked in sales an average of 11.2 years; their average age was 37.7 ; 281 were male ( 73.6 percent); and a majority had at least an undergraduate degree $(234-61.3$ percent). Respondents were compensated via salary (32.7\%), commission (19.1\%), or a combination of salary, commission, and bonus (48.2\%). According to information provided by the sales manager, no statistical difference in demographics was found between the salespeople who stayed and those salespeople who left or between the salespeople who completed a survey and those salespeople who did not.

\section{Measures}

The survey items appear in the appendix. Servant Leadership was measured using the 7 - item short form for the 28 - item scale developed by Liden et al. [51]. Liden et al. [51], using six samples of employees in three independent studies, found the short form of the scale was highly correlated with the longer version. Perceived Organizational Support was measured using five items from the Survey of Perceived Organizational Support developed by Eisenberger et al. [23]. Performance was measured using three items from the scale used by Low, Cravens, and Moncrief [52]. Turnover Intentions were measured with five items used by Wayne, Shore, and Liden [92]. Turnover was measured as a dichotomous variable and coded as 1 for salespeople still employed after one year and 2 for those salespeople who left.

\section{Measure Assessment}

Common method bias can be a serious problem in survey research ([70]. Several steps were taken to alleviate the problem of common method bias. First, the salespeople responded to questionnaire items related to servant leadership, POS, and turnover intentions while the sales managers rated the salesperson's performance. Second, the items were randomly dispersed in the questionnaire. Third, Harmon's one factor test was used as a statistical measure for common method variance. The one factor explained 27 percent of the variance, which is less than the recommended 50 percent level. While some concern exists for the use of Harmon's one factor test in its ability to detect common method bias [70], a recent study concluded that it "can detect biasing levels of CMV under conditions commonly found in survey-based marketing research" [27, p. 3197]. These results indicate that common method bias is probably not a serious problem.

\section{ANALYSIS AND RESULTS}

The results were analyzed using LISREL version 8. The means, standard deviations and correlation among the variables appear in the table.

\section{Correlation Matrix, Means, and Standard Deviations}

\begin{tabular}{|lccccc|}
\hline Servant leader & & & & \\
\hline POS & .31 & & & & \\
\hline Turnover Intentions & -.22 & -.35 & & & \\
\hline Performance & .27 & .33 & -.29 & & \\
\hline Turnover & -.19 & -.26 & .38 & -.30 & \\
\hline Means & 24.8 & 18.4 & 11.9 & 11.6 & 1.27 \\
\hline Standard Deviations & 5.1 & 4.2 & 5.3 & 2.3 & .45 \\
\hline
\end{tabular}


The measurement model indicated a good fit $(\chi 2=301.09, d f=180, p=.00$, GFI $=.92$, AGFI $=$ .89 , NFI $=.97$, RMSEA $=.046$ ). Based on the results of the confirmatory factor analysis, the hypothesized model was tested. The results for the hypothesized model also indicated a good fit $(\chi 2=305.95, d f=183, p=.00, \mathrm{GFI}=.92, \mathrm{AGFI}=.89, \mathrm{NFI}=.96, \mathrm{RMSEA}=.046)$.

Support was found for each of the hypotheses. Servant leadership is related positively to POS (Hypothesis 1) $(\beta=.32, t=5.18)$; servant leadership is related positively to performance (Hypothesis 2) $(\beta=.32, t=5.18)$; POS was related positively to performance (Hypothesis 3 ) $(\beta=$ $.20, t=3.11)$; POS is related negatively to turnover intentions (Hypothesis 4$)(\beta=-.28, t=4.63)$; performance was related negatively to turnover intentions (Hypothesis 5$)(\beta=-.22, t=3.51)$; performance is related negatively to turnover (Hypothesis 6$)(\beta=-.23, t=3.84)$; and turnover intentions were related negatively to turnover (Hypothesis 7$)(\beta=.31, t=5.48)$.

A second model tested the relationship between servant leadership and turnover intentions/turnover (R1). The results indicated that this model did not fit the data better than did the hypothesized model $(\Delta \chi 2=3.07, N S)$. The paths from servant leadership to turnover intentions $(\beta=.08, t=1.41)$ and servant leadership to turnover $\beta=.07, t=1.26)$ were insignificant.

\section{CONCLUSIONS}

Leadership has been an important focus of research for many years among a variety of employees. But, the study of leadership has been especially important in the area of professional selling because of the unique nature of a salesperson's job and its link to various outcomes, especially performance [e.g., 5, 40, 55, 57, 77].

The major purpose of this study was to examine outcomes of servant leadership, which recently has become an important area of research in professional selling [33]. Specifically, this study examined the relationship between servant leadership and performance, perceived organizational support, turnover intentions, and turnover. The results of this study have important theoretical and practical implications for managing the sales force.

\section{Theoretical Implications}

An important implication of these results is the relationship between servant leadership and performance. Research has analyzed variables related to sales force performance for more than thirty years [14]. Four studies have examined the relationship between servant leadership and outcome performance with samples of salespeople. This study confirmed the results of prior research $[33,42,77]$ indicating that servant leadership influences performance both directly and indirectly. In this study POS partially mediated the relationship between servant leadership and performance. An important aspect of this study is that it used actual performance data from the sales manager rather than relying on self-reported data. Thus, the salesperson's performance evaluation was separate from their opinion of their sales manager as a servant leader.

An important implication of these results is that servant leadership has a direct relationship with salespersons' level of POS. Many studies have shown the influence POS has on a variety of employees' behavior and organizational consequences. However, only a few studies have investigated POS within a sales context. This study expands on prior sales force research by showing that POS directly influences performance and turnover intentions. Sales managers who care about their salespeople's career development and puts the salesperson's best interests above their own development will instill a perception that the organization also cares about them. The type of behavior by the sales manager will lead to higher sales force 
performance and a lower intention to leave the organization.

An interesting theoretical implication of this study's results is that the lack of a direct, significant relationship between servant leadership and either turnover intentions or turnover. Few studies have examined the relationship between servant leadership and turnover intentions and only one study involved salespeople [43]. No study has looked at actual turnover data. The results indicated that sales managers perceived as servant leaders did not have a direct influence on either turnover intentions or turnover among this sample of salespeople.

\section{Managerial Implications}

Leadership has been the focus of much research in the sales area because of its relationship to various behaviors and outcomes (e.g., 42, 81]. But, as noted by Grisaffe, VanMeter, and Chonko [33], servant leadership has the potential of creating gains in outcomes beyond what is achieved by either transformational or transactional leadership. Thus, implementing a servant leadership approach can assist sales organizations to achieve desired goals.

The results presented here have several practical implications for sales organizations. Although not a construct in this study, research has indicated that servant leadership is related to ethical behavior of employees $[42,77]$. One of the items in the Liden et al. [50] measure of servant leadership, which was used in this study and the Schwepker and Schultz [77] study, asks about whether the sales manager would compromise his/her ethical principles in order to achieve success. The recent ethical scandal involving the sales practices at Wells Fargo emphasizes the importance of ethical leadership. Since serving others is a central component of servant leadership, hiring and/or promoting sales managers and executives who possess the traits of servant leadership may be a way to reduce unethical behavior in sales organizations. Another important practical implication is that sales managers who are viewed as servant leaders have a direct influence on the performance of their salespeople. Much research for many years has been devoted to understanding factors related to increasing salespersons' performance [e.g., 14, 28, 56, 88] including how leadership influences job performance [54, 57, $79,83]$. The sales manager who makes a salesperson's career development a priority, give the sales force freedom to make difficult decisions, and who has the ability to see when something is going wrong is viewed as being a servant leader. That type of sales manager can have a positive influence on a salesperson's performance.

The inclusion of POS in this study also has important implications for sales managers. The sales manager, acting as a servant leader, creates a perception among the sales force that the organization cares about them, takes great pride in their accomplishments, and is willing to help them when they have a problem. This perception that the organization supports their efforts will lead to higher performance and indirectly to lower turnover. Clearly, creating an environment where higher performance is achieved while reducing turnover, especially among the best performers, are goals that every organization wants to achieve with regard to their sales force. This study indicates that the sales manager plays a vital role in ascertaining and relaying the needs of the sales force to higher levels of management, which helps achieve these goals. However, failure to provide adequate support to the sales force can lead to lower performance and higher turnover.

\section{LIMITATIONS AND FUTURE RESEARCH OPPORTUNITIES}

This study, like all research, has some limitations. First, the data are cross-sectional. Future research can test the model within a single organization. Second, this study was limited to 
examining the relationship between servant leadership and certain outcome variables. Future studies may include other outcome variables such as organizational identification, psychological contract fulfillment, and organizational justice.

An important area of future research is to determine why and how sales managers who are viewed as servant leaders influence positive outcomes for the sales force. Have these sales managers received training that is different from other sales managers? If so, what training can organizations undertake to influence sales managers or salespeople who will become sales managers to become servant leaders? What role does upper management play in the development of servant leaders? What makes someone want to become a servant leader?

While the purpose of this study was to examine certain outcomes of servant leaders, future research should address antecedents of servant leadership. In addition, this study was the first one involving salespeople that examined the influence of servant leadership on POS. Future research needs to be undertaken to confirm these results.

In conclusion, this study has shown the importance of servant leadership on salespersons' POS and performance. Indirectly, through these two variables, servant leaders can influence the turnover process in the sales force. Hopefully, these results can show organizations the benefits of hiring and or promoting sales managers who can act as servant leaders to their salespeople.

\section{References}

Babakus, E., Yavas, U. and Ashill, N. J. (2011), “The Service Worker Burnout and Turnover Intentions: Roles of Person-Job Fit, Servant Leadership, and Customer Orientation," Services Marketing Quarterly, Vol 32 No.1, pp. 1731.

Bai, Y., Li, P., and Xi, Y. (2012), “The Distinctive Effects of Dual-Level Leadership Behaviors on Employees' Trust in Leadership: An Empirical Study from China.” Asia Pacific Journal of Management, Vol 29 No. 2, pp. $213-237$.

Bande, B., Pilar, F.F., Concepción, V.N.N. and Carmen, O.N. (2016), "Exploring the Relationship among Servant Leadership, Intrinsic Motivation and Performance in an Industrial Sales Setting." Journal of Business \& Industrial Marketing, Vol 31 No. 2, pp. 219-231.

Barbuto, J.E., and Wheeler, D.W. (2006), “Scale Development and Construct Clarification of Servant Leadership." Group \& Organization Management, Vol 31 No. 3, pp. 300-326.

Bass, B.M. (1997), "Personal Selling and Transactional/Transformational Leadership." Journal of Personal Selling \& Sales Management," Vol 17 No. 3,pp. 19-28.

Bass, B.M. (1985), Leadership and performance beyond expectations. New York: Free Press.

Bauer, T.N., Erdogan, B., Liden, R.C., and Wayne, S.J. (2006). "A Longitudinal Study of the Moderating Role of Extraversion: Leader-Member Exchange, Performance, and Turnover during New Executive Development." Journal of Applied Psychology, Vol 91 No. 2, pp. 298-310.

Blau, P. (1964), Exchange and Power in Social Life. New York: Wiley.

Boles, J.S., Dudley, G.W., Onyemah,V., Rouziès, D. and Weeks, W.W., (2012). "Sales Force Turnover and Retention: A Research Agenda.” Journal of Personal Selling \& Sales Management, Vol 32 No. 1, pp. 131.140.

Brashear, T.G., Manolis, C., and Brooks, C.M. (2005), "The Effects of Control, Trust, and Justice on Salesperson Turnover." Journal of Business Research, Vol 58 No. 3, pp. 241-249.

Burch, T.C. and Guarana, C. (2014), "The Comparative Influences of Transformational leadership and LeaderMember Exchange." Journal of Leadership Studies, Vol 8 No. 3, pp. 6-25.

Chakrabrty, S., Widing, R.E., and Brown, G. (2014), "Selling Behaviours and Sales Performance: The Moderating and Mediating Effects of Interpersonal Mentalizing." Journal of Personal Selling \& Sales Management, Vol 34 No. 2, pp. 112-122.

Chiniara, M. and Bentein, K. (2016), “Linking Servant Leadership to Individual Performance: Differentiating the Mediating Role of Autonomy, Competence and Relatedness Need Satisfaction.” Leadership Quarterly, Vol 27 No. 1, 
pp. 124-141.

Churchill, Jr., G.A., Ford, N.M., Hartley, S.W., and Walker, Jr. O.C. (1985), "The Determinants of Salesperson Performance: A Meta-analysis." Journal of Marketing Research, Vol 22 No. 2, pp. 103-118.

Cullen, K., Edwards, B., Casper, W., and Gue. K. (2014), "Employees' Adaptability and Perceptions of ChangeRelated Uncertainty: Implications for Perceived Organizational Support, Job Satisfaction, and Performance." Journal of Business \& Psychology, Vol 29 No. 2, pp. 269-280.

Darmon, R.Y. (2008), "The Concept of Salesperson Replacement Value: A Sales Force Turnover Management Tool." Journal of Personal Selling \& Sales Management, Vol 28 No. 3, pp. 211-232.

Darrat, M., Atinc, G. and Babin, B.J. (2016), "On the Dysfunctional Consequences of Salesperson Exhaustion." Journal of Marketing Theory \& Practice, Vol 24 No. 2, pp. 236-245.

Dawley, D., Houghton, J.D., and Bucklew, N.S. (2010), “Perceived Organizational Support and Turnover Intention: The Mediating Effects of Personal Sacrifice and Job Fit." Journal of Psychology, Vol 150 No. 3, pp. 238-257.

DeConinck, J.B. 2015. (2015), “Outcomes of Ethical Leadership among Salespeople." Journal of Business Research, Vol 68 No. 5, 1086-1093.

DeConinck, J.B. and Johnson, J.T. (2009), “The Effects of Perceived Supervisor Support, Perceived Organizational Support, and Organizational Justice on Turnover among Salespeople." Journal of Personal Selling \& Sales Management, Vol 29 No. 4, pp. 333-350.

Dulac, T., Coyle-Shapiro, J.A.M., Henderson, D.J., and Wayne, S.J. (2008), "Not All Responses to Breach are the Same: The Interconnection of Social Exchange and Psychological Contract Processes in Organizations." Academy of Management Journal, Vol 51 No. 6, pp. 1079-1098.

Eisenberger, R., Armeli, S., Rexwinkel, B., Lynch, P.D., and Rhoades, L. (2001), "Reciprocation of Perceived Organizational Support." Journal of Applied Psychology, Vol 86 No. 1, pp. 42-51.

Eisenberger, R., Huntington, R., Hutchison, S., and Sowa, D. (1986), “Perceived Organizational Support." Journal of Applied Psychology, Vol 71 No. 3, pp. 500-507.

Epitropaki, O. and Martin, R. (2013), "Transformational-Transactional Leadership and Upward Influence: The Role of Relative Leader-Member Exchanges (RLMX) and Perceived Organizational Support." Leadership Quarterly, Vol 24 No. 2, pp. 299-315.

Ehrhart, M.G. (2004), "Leadership and Procedural Justice Climate as Antecedents of Unit-Level Organizational Citizenship Behavior." Personnel Psychology, Vol 57 No. 1, pp. 61-94.

Fournier, C., Tanner Jr., J.F., Chonko, L.B., and Manoli, C. (2010), “The Moderating Role of Ethical Climate Salesperson Propensity to Leave." Journal of Personal Selling \& Sales Management, Vol 30 No. 1, pp. 7-22.

Fuller, C.M., Simmering, M.J., Atinc, G., Atinc, Y., and Babin, B.J. (2016), “Common Methods Variance Detection in Business Research." Journal of Business Research, Vol 69 No. 8, pp. 3192-3198.

Goad, E.A. and Jaramillo, F. (2014), "The Good, the Bad and the Effective: A Meta-Analytic Examination of Selling Orientation and Customer Orientation on Sales Performance." Journal of Personal Selling \& Sales Management, Vol. 34 No. 4, pp. 285-301.

Gouldner, A.W. (1960), "The Norm of Reciprocity: A Preliminary Statement." American Sociological Review, Vol 25 No. 2, pp. 161-178.

Greenleaf, R.K. (1970), The Servant as a Leader. Indianapolis, IN: Greenleaf Center.

Greenleaf, R.K. (1977), Servant Leadership: A Journey into the Nature of Legitimate Power and Greatness. New York: Paulist Press.

Griffeth, R.W., Hom, P.W., and Gaertner. S. (2000), "A Meta-Analysis of Antecedents and Correlates of Employee Turnover: Update, Moderator Tests, and Research Implications for the Next Millennium." Journal of Management, Vol 26 No. 3, pp. 463-488.

Grisaffe, D.B., VanMeter, R., and Chonko, L.B. (2016), "Serving First for the Benefit of Others: Preliminary Evidence of a Hierarchical Conceptualizations of Servant Leadership." Journal of Personal Selling \& Sales Management, Vol 36 No. 1, pp. 40-58.

Hair, J.F., Black, W.C., Babin, B.J., Anderson, R.E., and Tatham, R.L. (2009), Multivariate Data Analysis, $6^{\text {th }}$ ed. Upper Saddle, NJ.: Prentice Hall. 
Harris, K.J., Kacmar, M.K., and Witt, L.A. (2005), “An Examination of the Curvilinear Relationship between LeaderMember Exchange and Intent to Turnover.” Journal of Organizational Behavior, Vol 26 No. 4, pp. 363-378.

Harris, K.J., Wheeler, A.R., and Kacmar, M.K. (2009), "Leader-Member Exchange and Empowerment: Direct and Interactive Effects on Job Satisfaction, Turnover Intentions, and Performance.” Leadership Quarterly, Vol 20 No. 3, pp. 371-382.

Holtom, B.C., Mitchell, T.R., Lee, T.W., and Eberly. M.B. (2008), "Turnover and Retention Research: A Glance at the Past, a Closer Review of the Present, and a Venture into the Future." Academy of Management Annals, Vol 2 No. 1, pp. 231-274.

Hom, P.W., Carranikas, F., Prussia, G.E., and Griffeth, R.W. (1992), “A Meta-Analytical Structural Equations Analysis of a Model of Employee Behavior.” Journal of Applied Psychology, Vol 77 No. 6, pp. 890-909.

Hunter, E., Neubert, M.J., Perry, S.J., Witt, L.A., Penney, L.M., and Weinberger, E. (2013), "Servant Leaders Inspire Servant Followers: Antecedents and Outcomes for Employees and the Organization." Leadership Quarterly, Vol 24 No. 2, pp. 316-331.

Ingram, T.N., LaForge, R.W., Locander, W.B., McKenzie, S.B. and Podsakoff, P.M. (2005), "New Directions in Sales Leadership Research.” Journal of Personal Selling \& Sales Management, Vol 25 No. 2, pp. 251-273.

Jaramillo, F. and Mulki, J.P. (2008), "Sales Effort: The Intertwined Roles of the Leader, Customers, and the Salesperson.” Journal of Personal Selling \& Sales Management, Vol 28 No. 1, pp. 37-51.

Jaramillo, F., Bande, B. and Varela, J. (2015), "Servant Leadership and Ethics: A Dyadic Examination of Supervisor Behaviors and Salesperson Perceptions.” Journal of Personal Selling \& Sales Management, Vol 35 No. 2, pp. 108124.

Jaramillo, F., Grisafe, D.B., Chonko, L.B. and Roberts, J.A. (2009a), “Examining the Impact of Servant Leadership on Salesperson's Turnover Intentions. Journal of Personal Selling \& Sales Management, Vol 29 No. 4, pp. 351-366.

Jaramillo, F., Grisafe, D.B., Chonko, L.B., and Roberts, J.A. (2009b), “Examining the Impact of Servant Leadership on Sales Force Performance." Journal of Personal Selling \& Sales Management, Vol 29 No. 3, pp. 257-276.

Jaramillo, F., Mulki, J.P. and Solomon, P. (2006), “The Role of Ethical Climate on Salesperson's Role Stress. Job Attitudes, Turnover Intention, and Job Performance." Journal of Personal Selling \& Sales Management, Vol 26 No. 3, pp. 271-282.

Johnston, M.W., Futrell, C.W., Parasuraman, A. and Sager, J. (1988), “Performance and Job Satisfaction Effects on Salesperson Turnover.” Journal of Business Research, Vol 16 No. 1, pp. 67-83.

Lewin, J.E. and Sager, J.K. (2010), "The Influence of Personal Characteristics and Coping Strategies on Salespersons' Turnover.” Journal of Personal Selling \& Sales Management, Vol 30 No. 4, pp. 257-276.

Liden, R.C., Panaccio, A. Meusr, J.D., Hu, J. and Wayne, S.J. (2014a), "Servant Leadership: Antecedents, Processes, and Outcomes." In The Oxford Handbook of Leadership and Organization, edited by David V. Day, 357-379. New York: Oxford University Press.

Liden, R.C., Wayne, S.J., Liao, C. and Mauser, J.D. (2014b), “Servant Leadership and Serving Culture: Influence on Individual and Unit Performance.” Academy of Management Journal, Vol 57 No. 3, pp. 1434-1452.

Liden, R.C., Wayne, S.J., and Meuser, J.D. (2015), “Servant Leadership: Validation of a Short Form." The Leadership Quarterly, Vol 26 No. 2, pp. 254-269.

Liden R.C., Wayne, S.J., Zhao, H., and Henderson, D. (2008), "Servant Leadership: Development of a Multidimensional Measure and Multi-Level Assessment." The Leadership Quarterly, Vol 19 No. 2, pp. 161-172.

Low, G.S., Cravens, D.W. and Moncrief, W.C. (2001), "Antecedents and Consequences of Salesperson Burnout.” European Journal of Marketing, Vol 35 No. 5-6, pp. 587-611.

Lucas, Jr. G.H., Parasuraman, A., Davis, R.A., and Enis, B.A. (1987), “An Empirical Study of Salesforce Turnover.” Journal of Marketing, Vol 51 No. 3, pp. 34-59.

MacKenzie, S.B., Podsakoff, P.M., and Ahearne, M. (1998), "Some Possible Antecedents and Consequences of InRole and Extra-Role Salesperson Performance." Journal of Marketing, Vol 62 No. 3, pp. 87-98.

MacKenzie, S.B., Podsakoff, P.M., and Rich, G.A. (2001), "Transformational and Transactional Leadership and Salesperson Performance." Journal of the Academy of Marketing Science, Vol 29 No. 2, pp. 115-134.

Miao, C.F., and Evans, K. R. (2007), "The Impact of Salesperson Motivation on Role Perceptions and Job Performance - A Cognitive and Affective Perspective.” Journal of Personal Selling \& Sales Management, Vol. 27 No. 


\section{1, pp. 89-101.}

Mulki, J.P., Caemmerer, B. and Heggde, G.S. (2015), “Leadership Style, Salesperson's Work Effort and Job Performance: The Influence of Power Distance." Journal of Personal Selling \& Sales Management, Vol 35 No. 1, pp. 3-22.

Mulki, J.P., Jaramillo, F. and Marshall, G.W. (2007), “Lone Wolf Tendencies and Salesperson Performance.” Journal of Personal Selling \& Sales Management, Vol 27 No. 1, pp. 25-38.

Mulki, J.P., Jaramillo, F. and Locander, W.B. (2006), "Effects of Ethical Climate and Supervisory Trust on Salesperson's Job Attitudes and Intentions to Quit." Journal of Personal Selling \& Sales Management, Vol 26 No. 1, pp. 19-26.

Mullins, R. and Syam, N. (2014), "Manager-Salesperson Congruence in Customer and Job Outcomes: The Bright and Dark Sides of Leadership in Aligning Values." Journal of Personal Selling \& Sales Management Vol 34 No. 3, pp. 188-205.

Netemeyer, R.D., Boles, J.S., McKee, D.O. and McMurrian, R. (1997), “An Investigation into the Antecedents of Organizational Citizenship Behaviors in a Personal Selling Context." Journal of Marketing, Vol 61 No. 3, pp. 85-98.

Neubert, M.J., Carlson, D.S., Roberts, J.A., Kacmar, K.M. and Chonko, L.B. (2008), “Regulatory Focus as a Mediator of the Influence of Initiating Structure and Servant_Leadership on Employee Behavior." Journal of Applied Psychology, Vol 93 No 6, pp. 1220-1233.

Panaccio, A., Henderson, D.J., Liden, R.C., Wayne, S.J. and Cao, X. (2015), “Toward an Understanding of When and Why Servant Leadership Accounts for Employee Extra-Role Behaviors." Journal of Business and Psychology, Vol 30 No. 4, pp. 657-675.

Paparoidamis, N.G. and Guenzi, P. (2009), "An Empirical Investigation into the Impact of Relationship Selling and LMX on Salespeople's Behaviours and Sales Effectiveness." European Journal of Marketing, Vol 43 No. 7/8, pp. 1053-1075.

Parolini, J., Patterson, K., and Winston, B. (2009), “Distinguishing between Transformational and Servant Leadership." Leadership \& Organization Development Journal, Vol 30 No. 3, pp. 274-291.

Peltokorpi, V., Allen, D.G. and Froese, F. (2015), “Organizational Embeddedness, Turnover Intentions, and Voluntary Turnover: The Moderating Effects of Employee Demographic Characteristics and Value Orientation." Journal of Organizational Behavior, Vol 36 No. 2, pp. 292-321.

Pettijohn, C.E., Pettijohn, L.S. and Taylor, A.J. (2007), "Does Salesperson Perception of the Importance of Sales Skills Improve Sales Performance, Customer Orientation, Job Satisfaction, and Organizational Commitment, and Reduce Turnover?" Journal of Personal Selling \& Sales Management, Vol 27 No. 1, pp. 75-88.

Piercy, N.F., Cravens, D.W., Lane, N. and Vorhies, D.W. (2006), “Driving Organizational Citizenship Behaviors and Salesperson In-Role Behavior Performance: The Role of Management Control and Perceived_Organizational Support." Journal of the Academy of Marketing Science, Vol 34 No. 2, pp. 244-262.

Podsakoff, N.P., LePine, J.A. and LePine, M.A. (2007), “Differential Challenge Stressor-Hindrance Stressor Relationships with Job Attitudes, Turnover Intentions, Turnover, and Withdrawal Behavior: A Meta-Analysis." Journal of Applied Psychology, Vol 92 No. 2, pp. 438-454.

Podsakoff, P., MacKenzie, S.B., Lee, J.L. and Podsakoff, N.P. (2003), “Common Method Bias in Behavioral Research: A Critical Review of the Literature and Recommended Remedies." Journal of Applied Psychology, Vol 88 No. 5, pp. 879-903.

Rhoades, L. and Eisenberger, R. (2002), "Perceived Organizational Support: A Review of the Literature." Journal of Applied Psychology, Vol 86 No. 5, pp. 825-836.

Richardson, R. (999), “Measuring the Impact of Turnover on Sales.” Journal of Personal Selling \& Sales Management, Vol 19 No. 4, pp. 53-66.

Riggle, R.J., Edmondson, D.R. and Hansen, J.D. (2009), “A Meta-Analysis of the Relationship between Perceived Organizational Support and Job Outcomes: 20 Years of Research." Journal of Business Research, Vol 62 No. 10, pp. 1027-1030.

Russ, F.A. and McNeilly, K.A. (1995), “Links among Satisfaction, Commitment, and Turnover Intentions: The Moderating Effect of Experience, Gender, and Performance." Journal of Business Research, Vol 34 No. 1, pp. 57-65. 
Rutherford, B., Park, J. and Han, S.L. (2011), “Increasing Job Performance and Decreasing Salesperson Propensity to Leave: An Examination of an Asian Sales Force." Journal of Personal Selling \& Sales Management, Vol 31 No. 2 , pp. 171-184.

Sager, J.K., Varadarajan, P. and Futrell, C.M. (1988), “Understanding Salesperson Turnover: A Partial Evaluation of Mobley’s Turnover Process Model.” Journal of Personal Selling \& Sales Management, Vol 8 No. 1, pp. 21-35.

Schwepker, C.H. and Shultz, R.J. (2015), "Influence of the Ethical Servant Leader and Ethical Climate on Customer Value Enhancing Sales Performance.” Journal of Personal Selling \& Sales Management, Vol 35 No. 2, pp. 93-107.

Schwepker Jr, C.H. (2016), "Servant Leadership, Distributive Justice and Commitment to Customer Value in the Salesforce.” Journal of Business \& Industrial Marketing, Vol 31 No. 1, pp. 70-82.

Schwepker, C.H. (2015), "Influencing the Salesforce Through Perceived Leadership: The Role of Salesforce Socialization and Person-Organization Fit on Salesperson Ethics and Performance," Journal of Personal Selling \& Sales Management, Vol 35 No. 4, pp, 292-313.

Schwepker, C.H. (2013), "Improving Sales Performance Through Commitment to Superior Customer Value: The Role of Psychological Ethical Climate.” Journal of Personal Selling \& Sales Management, Vol 33 No. 4, pp. $389-402$.

Schwepker, C.H. and Good, D.J. (2010), “Transformational Leadership and its Impact on Sales Force Moral Ludgment. Journal of Personal Selling \& Sales Management, Vol 30 No. 4, pp. 299-318.

Schwepker, Jr., C.H. (2001), “Ethical Climate's Relationship to Job Satisfaction, Organizational Commitment, and Turnover Intention in the Salesforce." Journal of Business Research, Vol 54 No. 1, pp. 39-52.

Shannahan, K., Bush, A. and Shannahan, R. (2013), “Are Your Salespeople Coachable? How Salesperson Coachability, Trait, Competitiveness, and Transformational Leadership Enhance Sales Performance." Journal of the Academy of Marketing Science, Vol 41 No 1, pp. 40-54.

Stone, G.A., Russell, R.F., and Patterson, K. (2004), "Transformational versus Servant Leadership: A Difference in Leader Focus.” Leadership \& Organization Development Journal, Vol 25 No. 4, pp. 349-361.

Sweet, K.M., Witt, L.A. and Shoss, M.K. (2015), "The Interactive Effect of Leader-Member Exchange and Perceived Organizational Support on Employee Adaptive Performance.” Journal of Organizational Psychology, Vol 15 No. 1, pp. 49-62.

van Dierendonck, D. (2011), “Servant Leadership: A Review and Synthesis.” Journal of Management, Vol 37 No. 4 , pp. 1228-1261.

van Dierendonck, D., Stam, D., Boersma, P., de Windt, N., and Alkema, J. (2014), "Same Difference? Exploring the Differential Mechanisms Linking Servant Leadership and Transformational Leadership to Follower Outcomes." Leadership Quarterly, Vol 25 No. 3, pp. 544-562.

Verbeke, W., Dietz, B., and Verwaal, E. (2011), "Drivers of Sales Performance: A Contemporary Meta-Analysis. Have Salespeople Become Knowledge Broker?" Journal of the Academy of Marketing Science, Vol 39 No. 3, pp. 407-428.

Waldman, D.A., Carter, M.Z., and Hom, P.W. (2015), “A Multilevel Investigation of Leadership and Turnover Behavior.” Journal of Management, Vol 41 No. 6, pp. 1724-1744.

Walumbwa, F.O., Hartnell, C.A., and Oke, A. (2010), "Servant Leadership: Procedural Justice Climate, Service Climate, Employee Attitudes, and Organizational Citizenship Behavior: A Cross-Level Investigation." Journal of Applied Psychology, Vol 95 No. 3, pp. 517-529.

Wang, Guangping, Ma, X. (2013), "The Effect of Psychological Climate for Innovation on Salespeople's Creativity and Turnover Intention." Journal of Personal Selling \& Sales Management, Vol 33 No. 4, pp. 373-388.

Wayne, S.J., Shore, L.M., and Liden, R.C. (1997), "Perceived Organizational Support and Leader-Member Exchange: A Social Exchange Perspective.” Academy of Management Journal, Vol 40 No. 1, pp. 82-111.

Williams, C.R. and Livingstone, L.P. (1994), "Another Look at the Relationship between Performance and Voluntary Turnover.” Academy of Management Journal, Vol 37 No. 2, pp. 269-98.

Zhao, Chen, Yonghong, and Zhonhua Gao. “An Identification Perspective of Servant Leadership's Effects.” Journal of Managerial Psychology, Vol 31 No. 5, pp. 898-913.

Zhou, Yingying and Miao, Q. (2014), "Servant Leadership and Affective Commitment in the Chinese Public Sector: The Mediating Role of Perceived Organizational Support.” Psychological Reports, Vol 115 No. 2, pp. $381-395$.

Zimmerman, R.D. and Darnold, T.C. (2009), “The Impact of Job Performance on Employee Turnover Intentions and 


\section{Turnover Intentions}

\section{APPENDIX}

1. I am actively looking for a job outside of my company.

2. As soon as I can find a better job, I'll leave my company.

3. I am seriously thinking about quitting my job.

4. I often think about quitting my job.

5. I think I will be working at another company five years from now (Reverse scored).

\section{Perceived Organizational Support}

1. My organization takes great pride in my accomplishments.

2. My organization really cares about my well-being.

3. My organization strongly considers my goals and values.

4. My organization is willing to help me if I need help.

5. Help is available from the organization when I have a problem.

\section{Servant Leadership}

1. My sales manager can tell if something work-related is going wrong.

2. My sales manager makes my career development a priority.

3. I would seek help from my sales manager if I had a personal problem.

4. My sales manager emphasized the importance of giving back to the community.

5. My sales manager puts my best interests ahead of his/her own.

6. My sales manager gives me the freedom to handle difficult situations in the way that I feel is best.

7. My sales manager would NOT compromise ethical principles in order to achieve success.

\section{Performance}

(items measured on a scale ranging from 1 "needs improvement" to 5 "outstanding")

1. Achieving annual sales targets and other objectives.

2. Understanding customer needs and work processes.

Keeping expenses at acceptable levels. 


\section{Hypothesized Model}

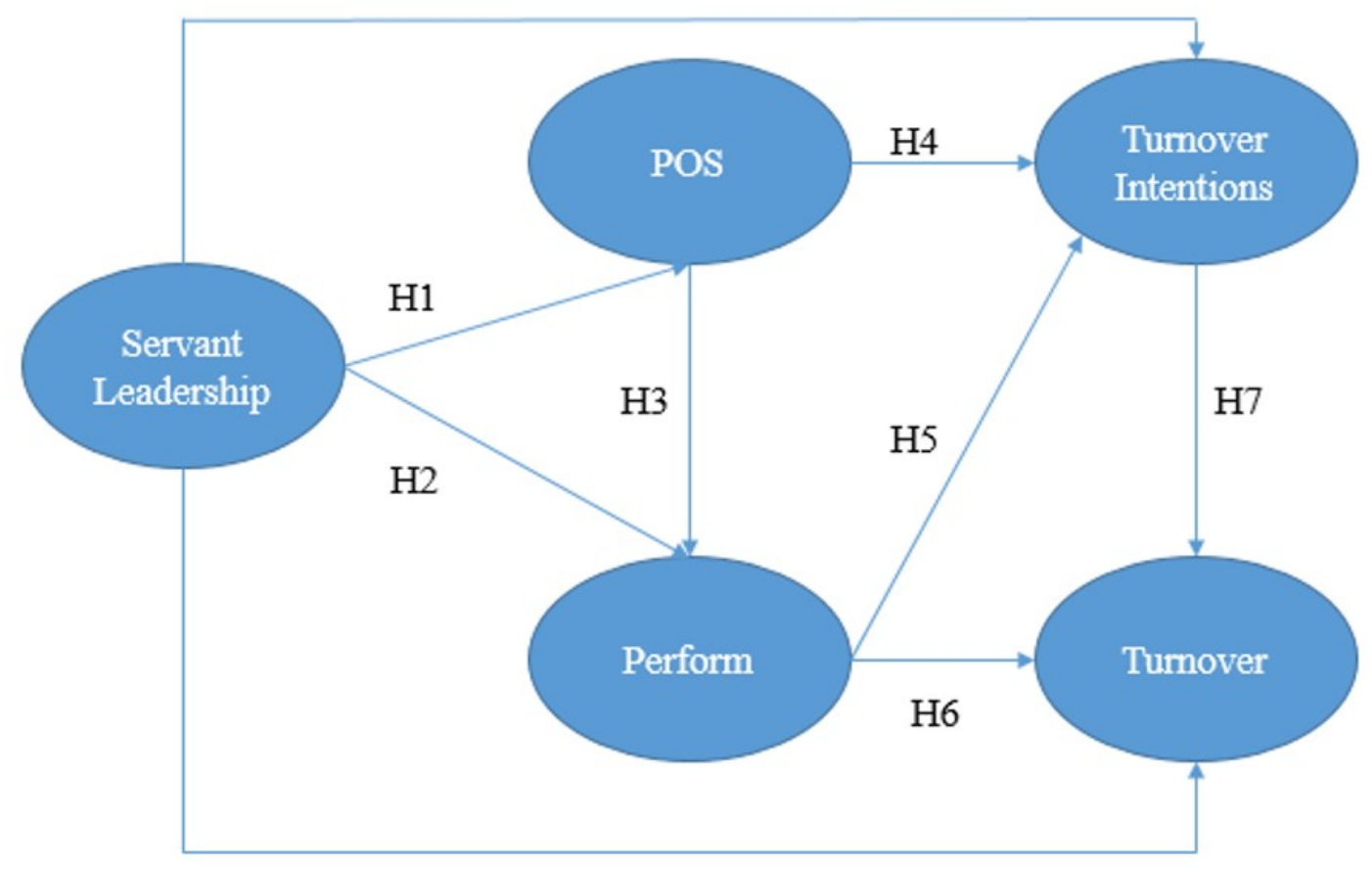

